\title{
KEANEKARAGAMAN INSEKTA YANG TERDAPAT DI HUTAN PENDIDIKAN DAN PELATIHAN UNIVERSITAS MUHAMMADIYAH BENGKULU
}

\author{
Pariyanto ${ }^{1}$, Reny Dwi Riastuti ${ }^{2}$, Mifta Nurzorifah ${ }^{3}$ \\ Univeritas Muhammadiyah Bengkulu ${ }^{1,3}$ \\ STKIP Lubuk Linggau ${ }^{2}$ \\ pariyantoyanto914@gmail.com ${ }^{1}$
}

\begin{abstract}
ABSTRAK
Tujuan penelitian ini adalah untuk mengetahui keanekaragaman Insekta yang terdapat di hutan Pendidikan dan Pelatihan Universitas Muhammadiyah Bengkulu di Kabupaten Bengkulu Tengah. Metode yang dilakukan dalam penelitian ini yaitu metode survey. Pengamatan dilakukan secara langsung ke lokasi penelitian, serta pengambilan sampel dilakukan dengan menjelajahi lokasi penelitian. Penelitian dilakukan pada bulan Desember-Januari 2019. Hasil penelitian, insekta yang ditemukan di Hutan Pendidikan dan Pelatihan Universitas Muhammadiyah Bengkulu Kabupaten Bengkulu Tengah diperoleh 326 individu yang terdiri dari 13 famili dengan 16 spesies yaitu: Pheropsophus verticalis (Kumbang macan), Tenebrio molitor (Kumbang ulat), Leptocorisa acuta (Walang sangit), Tibicen linnei (Tonggeret), Dolichovespula sylvestris (Tawon pohon), Oecophylla smaragdina (Semut rang-rang), Dolichoderus thoracicus (Semut hitam), Tanaecia iapis (Kupu-kupu hitam biru), Idea stoli (Kupu-kupu bintik hitam), Valanga nigricornis (Belalang kayu), Acrida conica (Belalang hijau), Gryllus bimaculatus (Jangkrik), Scambophyllumson guinolentum (Belalang katydid), Gryllotapa orientalis (Anjing tanah), Pantala flavescens (Capung ciwet), Phaenopharos khaoyaiensis (Belalang ranting). Dari seluruh famili Insekta yang ditemukan diperoleh Indeks Keanekaragaman sebesar 1,031 yang menunjukan bahwa keanekaragaman tergolong sedang. Hasil pengukuran faktor ekologi di hutan yaitu suhu berkisar antara $26^{\circ} \mathrm{C}-31^{\circ} \mathrm{C}$ dan kelembaban $87 \%-90 \%$. Simpulan, tingkat keanekaragaman insekta di hutan Pendidikan dan Pelatihan Universitas Muhammadiyah Bengkulu di Kabupaten Bengkulu Tengah tergolong sedang, dengan ditemukannya 13 famili dan 16 spesies insekta.
\end{abstract}

Kata Kunci : keanekaragaman, hutan, insekta.

\section{ABSTRACT}

The purpose of this study was to determine the diversity of insects found in the forests of Education and Training at the University of Muhammadiyah Bengkulu in Bengkulu Tengah Regency. The method used in this study is the survey method. Observations were made directly to the study site, and sampling was done by exploring the research location. The study was conducted in December-January 2019. The results of the study, insects found in the Forest of Education and Training University of Muhammadiyah Bengkulu, Central Bengkulu District were obtained 326 individuals consisting of 13 families with 16 species, namely: Pheropsophus verticalis (Tiger beetle), Tenebrio molitor (Beetle caterpillar), Leptocorisa acuta (Walang sangit), Tibicen linnei (Tonggeret), Dolichovespula 
sylvestris (Tree wasp), Oecophylla smaragdina (Ant-rang), Dolichoderus thoracicus (Black ant), Tanaecia iapis (Tree wasp), Oecophylla smaragdina (Antrangung), Dolichoderus thoracicus (Black ant), Tanaecia iapis (Tree wasp) stoli (black spotted butterfly), Valanga nigricornis (wood grasshopper), Acrida conica (green grasshopper), Gryllus bimaculatus (cricket), Scambophyllumson guinolentum (katydid grasshopper), Gryllotapa orientalis (ground dog), Gryllus bimaculatus (cricket), Scambophyllumson guinolentum (katydid grasshopper), Gryllotapa orientalis (earth dog), Gryllus bimaculatus (cricket), Scambophyllumson guinolentum (grasshopper katydid) Phaenopharos khaoyaiensis (grasshopper twigs). From all Insect families found, a Diversity Index of 1.031 was obtained, indicating that diversity was classified as moderate. The results of measurements of ecological factors in the forest are temperatures ranging from $260 \mathrm{C}-31 \mathrm{oC}$ and humidity $87 \%-90 \%$. In conclusion, the level of insect diversity in the forests of Education and Training at the University of Muhammadiyah Bengkulu in Bengkulu Tengah Regency is classified as moderate, with the discovery of 13 families and 16 species of insects.

Keywords :diversity, forest, insecta.

\section{PENDAHULUAN}

Indonesia merupakan salah satu negara yang disebut "Mega Biodiversity" setelah Brazil dan Madagaskar. Diperkirakan 25\% aneka spesies yang berada di Indonesia, yang mana dari setiap jenis tersebut terdiri dari ribuan plasma nutfah dalam kombinasi yang cukup unik sehingga terdapat aneka gen dalam individu. Secara total keanekaragaman hayati di Indonesia adalah sebesar 325.350 jenis flora dan fauna. Keanekaragaman adalah variabilitas antar makhluk hidup dari semua sumber daya, termasuk di daratan, ekosistem-ekosistem perairan, dan komplek ekologis termasuk juga keanekaragaman dalam spesies diantara spesies dan ekosistemnya. Sepuluh persen dari ekosistem alam berupa suaka alam, suaka margasatwa,taman nasional, hutan lindung, dan sebagian lagi bagi kepentingan pembudidayaan plasma nutfah, dialokasikan sebagai kawasan yang dapat memberi perlindungan bagi keanekaragaman hayati (Arief, 2001 dalam Rahmawaty, 2004).

Provinsi Bengkulu berada di sebelah barat pegunungan Bukit Barisan, terletak di antara $2^{\circ} 16^{\prime \prime}-03^{\circ} 31^{\prime \prime}$ LS dan $101^{\circ} 01^{\prime}-103^{\circ} 41^{\prime}$ BT, diapit oleh Propinsi Sumatera Barat di sebelah utara dan Provinsi Lampung di sebelah Selatan. Bengkulu didominasi oleh perbukitan dengan kawasan hutan seluas 920.964 ha atau 46.54\% dari luas daratan Propinsi Bengkulu (1.978.870 ha). Diantara kawasan hutan di Bengkulu sebagian merupakan hutan lindung Bukit Barisan yang termasuk dalam rangkaian hutan tropis yang terbentang dari Utara hingga Selatan Pulau Sumatera.Berdasarkan SK Menteri Lingkungan Hidup dan Kehutanan Nomor 425/Menlhk/Setjen/PLA.O/6/2016 tentang penetapan kawasan hutan dengan tujuan khusus, dari kawasan hutan lindung tersebut seluas \pm 2.000 
ha yang terdapat di Kabupaten Bengkulu Tengah, Provinsi Bengkulu ditetapkan sebagai Hutan Pendidikan dan Pelatihan yang pengelolaannya diserahkan kepada Universitas Muhammadiyah Bengkulu (Hasan, Yuniarti \& Kasmiruddin, 2018).

Hutan merupakan suatu ekosistem natural yang telah mencapai keseimbangan klimaks dan merupakan komunitas pertumbuhan paling besar yang mampu pulih kembali dari perubahan-perubahan yang dideritanya, sejauh tidak melampaui batas-batas yang dapat ditoleransi.Hutan bukan semata-mata kumpulan pohon-pohon yang hanya dieksploitasi dari hasil kayunya saja, tetapi hutan merupakan persekutuan hidup alam hayati atau suatu masyarakat tumbuhan yang kompleks yang terdiri atas pohon-pohon, semak, tumbuhan bawah, jasad renik tanah, hewan, dan alam lingkungannya. Semuanya itu mempunyai keterkaitan dalam hubungan ketergantungan satu sama lain (Arief, 2001).

Menurut Sembel (2010) Indonesia adalah Negara yang secara umum memiliki iklim tropis, dimana wilayah ini termasuk daerah tropis lembab atau basah yang kaya akan tumbuhan dan tanaman tropis. Serangga merupakan organisme terbesar yang terdapat hampir diberbagai tempat habitat yaitu didarat, dalam air, tanah, udara, perpohonan, biji-bijian, tubuh manusia dan hewan.

Berdasarkan survei awal di kawasan Hutan Pendidikan dan Pelatihan Universitas Muhammadiyah Bengkulu yang terletak di Kabupaten Bengkulu Tengah ditemukan beberapa jenis-jenis Insekta seperti kupu-kupu, rayap, kumbang, capung dan belalang. Sebelumnya sudah pernah dilakukan penelitian oleh Leza Aprian tentang keanekaragaman insect yang terdapat di Hutan Pendidikan dan Pelatihan Universitas Muhammadiyah Bengkulu Kabupaten Bengkulu Tengah pada titik koordinat 03049'54" LS 102017'5" BT hasil dari spesies Insekta yang ditemukan yaitu, Neoucurtilla hexadactyla, Valanga nigricornis, Phlaeoba fumosa, Scudderia pilstillata, Gryllus mitratus, Heliocopris standingeri, Carcinops pimilio, Oryctes rhinoceros L, Dolichoderu thoracicus, Oecophylla smaragdina, Xylocopa virginica, Leptocorixa acuata, Physomerus grosspes, Attacus atlas. Dengan keadaan lingkungan yang banyak terdapat tumbuhan epifit yang menempel di pepohonan, tanaman herba, tumbuhan liana.Sedangkan lokasi yang akan diteliti titik koordinat 03040'10" LS 102032'55" dengan keadaan lingkungan yang banyak terdapat tumbuhan berbunga, tanaman herba, palem, tanaman pakuan besar pada kawasan hutan tersebut. Informasi tentang Insekta di Hutan Pendidikan dan Pelatihan Universitas Muhammadiyah Bengkulu Kabupaten Bengkulu Tengah masih sedikit sehingga dirasa perlu untuk melakukan penelitian mengenai Keanekaragaman Insekta yang terdapat di hutan Pendidikan dan Pelatihan Universitas Muhammadiyah Bengkulu Kabupaten Bengkulu Tengah.

\section{METODE PENELITIAN}

Penelitian ini telah dilaksanakan pada bulan Desember - Januari 2019. Di Hutan Pendidikan dan Pelatihan Universitas Muhammadiyah Bengkulu 
Kabupaten Bengkulu tengah dengan titik koordinat LS 0340'10" BT 102³2'55" Kabupaten Bengkulu Tengah, dengan luas areal penelitian \pm 2 hektar sedangkan indentifikasi akan dilakukan di Laboratorium Biologi Universitas Muhammadiyah Bengkulu.

Alat yang digunakan adalah Termohygrometer, alat tulis, kamera, kaca pembesar, pinset, penggaris, dan jaring serangga (Insect net), toples, kapas, GPS, alat suntik, kertas label, amplop, kotak koleksi. Bahan yang dipergunakan dalam penelitian yaitu Alkohol 70\% dan formalin dengan 4\%, kloroform.

Penelitian ini dilakukan dengan melakukan servey langsung kelapangan. Pengambilan data setiap serangga dilakukan dengan menggunakan metode jelajah yaitu menjelajahi lokasi penelitian sambil menangkap serangga bersayap ataupun tidak bersayap yang ditemukan dengan menggunakan jaring serangga (insecnet).

Pengambilan sampel dilakukan langsung ketempat lokasi penelitian yaitu di Hutan Pendidikan dan Pelatihan Universitas Muhammadiyah Bengkulu Kabupaten Bengkulu Tengah. Penangkapan dilakukan di lokasi penelitian pada waktu pagi hari dan siang hari. Alasan penangkapan pada pagi hari karena serangga ini paling aktif mencari makan pada waktu bunga banyak mengeluarkan cairan yang berupa madu. Sedangkan penangkapan pada siang hari dilakukan karena serangga selalu terbang pada siang hari dan istirahat pada malam hari. (Jumar, 2000). Serangga yang ada ditanah, batang dan daun serta yang berukuran kecil di daerah areal jika memungkinkan ditangkap dengan tangan, dan di amati dengan lup. Serangga yang tertangkap segera dibawa dengan cara di bius bagi serangga yang besar dibius dengan kloroform. Caranya serangga dimasukkan kedalam toples yang ditutup rapat, kemudian kedalamnya dimasukkan kapas yang sudah dibasahi klorofrom. Tunggu beberapa menit maka serangga itu akan mati setelah serangga tersebut mati lalu dipisahkan menurut kesamaan jenisnya, dan dimasukkan kedalam kotak koleksi yang telah disiapkan. Sedangkan serangga yang relative kecil cukup direndam saja dengan larutan alkohol, untuk serangga yang berukuran cukup besar dengan menyuntikkan formalin ke dalam tubuh serangga. Setelah selesai pengambilan sampel, selanjutnya identifikasi ciri-ciri morfologinya seperti bentuk antena, sayap, tungkai, kepala, mata, alat mulut, toraks dan abdomen.

Pengukuran faktor ekologi meliputi suhu, Kelembaban dan Cara pengukurannya diuraikan sebagai berikut: Suhu udara, Suhu diukur 3 kali dalam sehari yaitu, pagi jam 08.00-10.00, siang jam 12.00-14.00 dan sore jam 15.0017.00. Dengan termohygrometer dengan cara menggantungkan alat tersebut dilokasi penelitian. Kelembaban udara, Kelembaban di ukur 3 kali dalam sehari yaitu, pagi jam 08.00-10.00 Wib, siang jam 12.00-14.00, sore jam 15.00-17.00 Wib.

Kegiatan di laboratorium yaitu melakukan identifikasi jenis jenis serangga yang diperoleh. Serangga tersebut sebelum diidentifikasi terlebih dahulu di buat insektarium, difoto, kemudian diidentifikasi dengan menggunakan alat seperti: 
kaca pembesar (luv), pinset, dan alat-alat yang digunakan untuk mengamati morfologi jenis-jenis serangga. Untuk identifikasi jenis-jenis serangga di gunakan buku panduan sebagai acuan untuk identifikasi dan determinasi yaitu: Kunci Determinasi Serangga, Lilies (1991), Pengenalan Serangga Edisi Ke-enam, Borror (1992).

Data yang didapatkan di lapangan dianalisis dengan menggunakan rumus indeks keanekaragaman menurut Shannon-Winer dalam (Soegianto,1994) sebagai berikut :

$$
\mathrm{H}^{\prime}=-\sum p i \log p i
$$

$$
\begin{aligned}
& \text { Keterangan : } \\
& \mathrm{H}^{\prime}=\text { indeks indeks keanekaragaman jenis } \\
& \mathrm{Pi}=\mathrm{ni} / \mathrm{N} \\
& \mathrm{ni}=\text { jumlah individu dari masing }{ }^{2} \text { spesies } \\
& \mathrm{N}=\text { jumlah seluruh individu }
\end{aligned}
$$

Kriteria yang digunakan untuk meninterpretasikan keanekaragaman Shannon dan Winner yaitu :

a. $\mathrm{H}^{\prime}<1=$ menunjukan keanekaragaman rendah.

b. $1<\mathrm{H}^{\prime}<3=$ menunjukan keanekaragaman sedang

c. c. $H^{\prime}>3=$ menunjukan keanekaragaman tinggi

\section{HASIL PENELITIAN \\ Deskripsi Lokasi Penelitian}

Hutan Pendidikan dan Pelatihan Universitas Muhammadiyah Bengkulu ditetapkan menurut SK dengan nomor SK> 425/Menlhk/Setjen/PLA.O/6/2016 keputusan menteri lingkungan hidup dan kehutanan tentangpenetapan kawasan hutan dengan tujuan khusus pada kawasan hutan lindung yang terletak di Kabupaten Bengkulu Tengah, Provinsi Bengkulu seluas \pm 2.000 hektar sebagai Hutan Pendidikan dan Pelatihan, luas daerah yang diteliti $2 \mathrm{Ha}$ dengan titik koordinat LS 03o40'10" BT 102o32'55" yang terletak disebelah kiri jalan Raya dari Kabupaten Kepahiyang menuju Kabupaten Bengkulu Tengah dan memiliki Batas wilayah sebagai berikut:

1. Sebelah Utara : Berbatas dengan Kabupaten Bengkulu Utara

2. Sebelah Timur : Berbatas dengan Kabupaten Kepahiang

3. Sebelah Selatan : Berbatas dengan Kabupaten Seluma

4. Sebelah Timur :Berbatas dengan Kota Bengkulu (LKIP Bkl Tengah, 2016)

Dari penelitian yang telah dilakukan di Hutan Pendidikan dan Pelatihan Universitas Muhammadiyah Bengkulu Kabupaten Bengkulu Tengah.Insekta yang ditemukan sebanyak 326 individu yang terdiri dari 8 ordo, 13 famili dan 16 spesies (tabel 1.). 
Tabel 1. Jenis-jenis Insekta yang Ditemukan

\begin{tabular}{lllc}
\hline \multicolumn{1}{c}{ Ordo } & \multicolumn{1}{c}{ Famili } & \multicolumn{1}{c}{ Spesies } & Total \\
\hline Coleoptera & Carabidae & Pheropsophus verticalis & 12 \\
\cline { 2 - 4 } & Tenebrionidae & Tenebrio molitor & 9 \\
\hline Hemiptera & Alydidae & Leptocorisa acuta & 57 \\
\hline Homoptera & Cicadidae & Tibicen linnei & 6 \\
\hline Hymenoptera & Vespidae & Dolichovespua sylvestris & 26 \\
\cline { 2 - 4 } & Formicidae & Oecophylla smaragdina & 63 \\
\cline { 2 - 4 } & & Dolichoderus thoracicus & 60 \\
\hline \multirow{2}{*}{ Lepidoptera } & Nymphalidae & Tanaecia iapis & 11 \\
\cline { 2 - 4 } & & Idea stoli & 18 \\
\hline Orthoptera & Acricidae & Valanga nigricornis & 13 \\
\cline { 2 - 4 } & & Acrida conica & 13 \\
\cline { 2 - 4 } & Gryllidae & Gryllus bimaculatus & 15 \\
\cline { 2 - 4 } & Tettigoniidae & Scambophyllum sanguinolentum \\
\cline { 2 - 4 } & Gryllotalpidae & Gryllotalpa orientalis \\
\hline Odonata & Libellulidae & Pantala flavescens & 4 \\
\hline Phasmida & Diapheromeridae & Phaenopharos khaoyaiensis \\
\hline
\end{tabular}

Berdasarkan tabel 1 di atas dapat dilihat dari hasil penelitian yang telah dilakukan di Hutan Pendidikan dan Pelatihan Universitas Muhammadiyah Bengkulu Kabupaten Bengkulu Tengah ditemukan sebanyak 326 individu dari 16 spesies yang termasuk ke dalam 8 ordo, 13 famili. Ordo yang paling banyak ditemukan familinya yaitu Orthoptera, Ordo yang relatif banyak ditemukan familinya yaitu Coleoptera, Hymenoptera. Sedangkan Ordo yang paling sedikit ditemukan familinya yaitu Hemiptera, Homoptera, Lepidoptera, Odonata dan Phasmida.

Tabel 2. Jumlah Insekta yang Ditemukan

\begin{tabular}{lllc}
\hline \multicolumn{1}{c}{ Famili } & \multicolumn{1}{c}{ Spesies } & \multicolumn{1}{c}{ Nama Daerah } & Total \\
\hline Carabidae & Pheropsophus verticalis & Kumbang macan & 12 \\
\hline Tenebrionidae & Tenebrio molitor & Kumbang ulat & 9 \\
\hline Alydidae & Leptocorisa acuta & Walang sangit & 57 \\
\hline Cicadidae & Tibicen linnei & Tonggeret & 6 \\
\hline Vespidae & Dolichovespula sylvestris & Tawon pohon & 26 \\
\hline Formicidae & Oecophylla smaragdina & Semut merah & 63 \\
\cline { 2 - 4 } & Dolichoderus thoracicus & Semut itam & 60 \\
\hline Nymphalidae & Tanaecia iapis & Kupu-kupu hitam biru & 11 \\
\cline { 2 - 4 } & Idea stoli & Kupu-kupu bintik & 4 \\
\hline Acricidae & Valanga nigricornis & Belalang kayu & 18 \\
\cline { 2 - 4 } & Acrida conica & Belalang ijo & 15 \\
\hline Gryllidae & Gryllus bimaculatus & Jangkrik Hitam & 13 \\
\hline Tettigoniidae & Scambophyllum & Belalang daun & \\
\hline & sanguinolentum & & \\
\hline
\end{tabular}




\begin{tabular}{lllc}
\hline Gryllotalpidae & Gryllotalpa orientalis & Orong-orong & 3 \\
\hline Libellulidae & Pantala flavescens & Kinjang & 15 \\
\hline Diapheromeridae & Phaenopharos khaoyaiensis & Belalang lidi & 4 \\
\hline \multicolumn{2}{c}{ Jumlah } & & 326
\end{tabular}

Berdasarkan tabel 2 di atas diketahui bahwa hasil penelitian yang telah dilakukan di Hutan Pendidikan dan Pelatihan Universitas Muhammadiyah Bengkulu Kabupaten Bengkulu Tengah ditemukan sebanyak 326 individu yang terdiri dari 16 spesies yang termasuk ke dalam 13 famili. Sedangkan untuk tingkat famili yang paling banyak ditemukan spesiesnya yaitu famili Formicidae, Nymphalidae, Acrididae. Sedangkan famili yang paling sedikit ditemukan spesiesnya yaitu Carabidae, Tenebrionidae, Alydidae, Cicadidae, Vespidae, Gryllidae, Tettigonidae, Gryllotalpidae, Libellulidae, Diapheromeridae. Untuk tingkat spesies, spesies yang paling banyak ditemukan yaitu Oecophylla smaragdina dan Dolichoderus thoracicu. Sedangkan spesies yang paling sedikit ditemukan yaitu Gryllotapa orientalis.

Berdasarkan Tabel 3 di bawah ini dapat dilihat bahwa hasil penelitian yang telah dilakukan di Hutan Pendidikan dan Pelatihan Universitas Muhammadiyah Bengkulu Kabupaten Bengkulu Tengah diperoleh Indeks Keanekaragaman Jenis (H') yaitu 1,031. Jadi berdasarkan tabel di atas jumlah Indeks Keanekaragaman Jenis Insekta di Hutan Pendidikan dan Pelatihan Universitas Muhammadiyah Bengkulu Kabupaten Bengkulu Tengah dikategorikan Indeks Keanekaragaman Jenisnya sedang.

Tabel 3. Indeks Keanekaragaman Jenis (H') Insekta

\begin{tabular}{|c|c|c|c|c|c|}
\hline Spesies & Jumlah (ni) & $\mathbf{P i}$ & $\log \mathbf{P i}$ & $\mathbf{P i} \log \mathbf{P i}$ & H' \\
\hline Pheropsophus verticalis & 12 & 0.037 & -1.434 & -0.053 & 0,053 \\
\hline Tenebrio molitor & 9 & 0.028 & -1.559 & -0.043 & 0,043 \\
\hline Leptocorisa acuta & 57 & 0.175 & -0.757 & -0.132 & 0,132 \\
\hline Tibicen linnei & 6 & 0.018 & -1.735 & -0.031 & 0,031 \\
\hline Dolichovespula sylvestris & 26 & 0.079 & -1.098 & -0.088 & 0,088 \\
\hline Oecophylla smaragdina & 63 & 0.193 & -0.714 & -0.138 & 0,138 \\
\hline Dolichoderus thoracicus & 60 & 0.184 & -0.735 & -0.135 & 0,135 \\
\hline Tanaecia iapis & 11 & 0.034 & -1.472 & -0.049 & 0,049 \\
\hline Idea stoli & 4 & 0.012 & -1.911 & -0.023 & 0,023 \\
\hline Valanga nigricornis & 18 & 0.055 & -1.258 & -0.069 & 0,069 \\
\hline Acrida conica & 15 & 0.046 & -1.337 & -0.061 & 0,061 \\
\hline Gryllus bimaculatus & 13 & 0.039 & -1.399 & -0.056 & 0,056 \\
\hline $\begin{array}{l}\text { Scambophyllum } \\
\text { sanguinolentum }\end{array}$ & 10 & 0.031 & -1.513 & -0.046 & 0,046 \\
\hline Gryllotalpa orientalis & 3 & 0.009 & -2.036 & -0.019 & 0,019 \\
\hline Pantala flavescens & 15 & 0.046 & -1.337 & -0.061 & 0,061 \\
\hline $\begin{array}{l}\text { Phaenopharos } \\
\text { khaoyaiensis }\end{array}$ & 4 & 0.012 & -1.911 & -0.023 & 0,023 \\
\hline Jumlah & 326 & 0.998 & $-20,295$ & $-1,031$ & 1,031 \\
\hline
\end{tabular}


Tabel 4. Hasil Pengukuran Faktor Ekologi

\begin{tabular}{lcccc}
\hline \multicolumn{1}{c}{ Faktor Ekologi } & Pagi & Siang & Sore & Rata-Rata \\
\hline Suhu udara & $26^{\circ} \mathrm{C}$ & $31^{\circ} \mathrm{C}$ & $28{ }^{\circ} \mathrm{C}$ & $28^{\circ} \mathrm{C}$ \\
Kelembaban udara & $90 \%$ & $87 \%$ & $89 \%$ & $88 \%$ \\
\hline
\end{tabular}

Berdasarkan tabel 4 di atas dapat dilihat bahwa hasil pengukuran faktor ekologi pada lokasi penelitian di Hutan Pendidikan dan Pelatihan Universitas Muhammadiyah Bengkulu Kabupaten Bengkulu Tengah diperoleh suhu udara berkisaran antara $26^{\circ} \mathrm{C}-31^{\circ} \mathrm{C}$ dengan rata-rata $28^{\circ} \mathrm{C}$. Sedangkan kelembaban udara berkisar antara $87 \%-90 \%$ dengan rata-rata $88 \%$.

\section{Deskripsi Insekta yang Ditemukan}

Deskripsi Insekta yang ditemukan di Hutan Pendidikan dan Pelatihan Universitas Muhammadiyah Bengkulu Kabupaten Bengkulu Tengah

1. Pheropsophus verticalis (Kumbang macan)

a. Klasfikasi

Kingdom : Animalia

Filum : Athropoda

Kelas : Insekta

Ordo : Coleoptera

Famili : Carabidae

Genus : : Pheropsophus

Spesies : : Pheropsophus verticalis

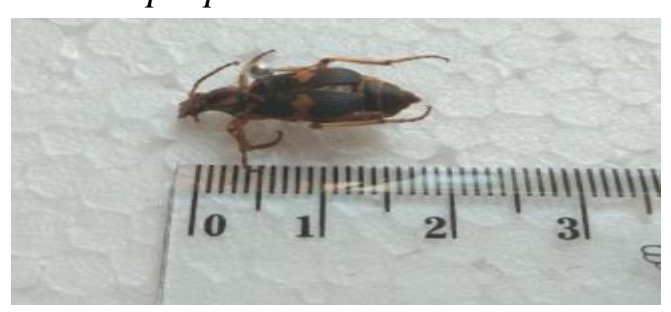

Gambar 1. Pheropsophus verticalis

b. Deskripsi

Ciri-ciri Pheropsophus verticalis adalah memiliki ukuran panjang tubuh 1,8 cm dan lebar tubuh $0,7 \mathrm{~cm}$, sayap berwarna hitam dan sedikit berwarna orange di bagian tubuh, memiliki 1 pasang antenna seperti benang, memiliki 3 pasang kaki yang ramping, mengeluarkan bau busuk.

Ciri-ciri lainnya memiliki bervariasi dalam ukuran, bentuk dan warna. Tubuh pipih dengan alur-alur membujur pada sayap depan, umumnya hitam dan berkilap, kadang-kadang cerah. Kepala dan mata hampir selalu lebih sempit dari pronotum, antenna seperti benang, kaki panjang dan ramping (Lilies, 1991). 
2. Tenebrio molitor (Kumbang ulat)

a. klasfikasi

Kingdom : Animalia

Filum : Athropoda

Kelas : Insekta

Ordo : Coleoptera

Famili : Tenebrionidae

Genus : : Tenebrio

Spesies : : Tenebrio molitor

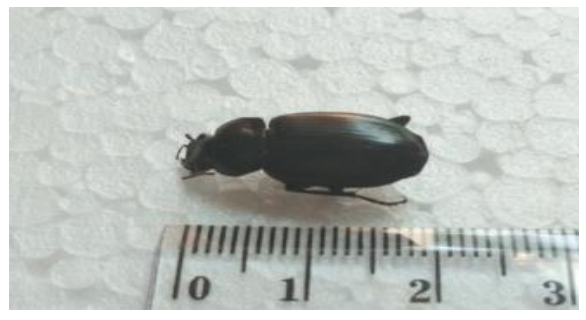

Gambar 2. Tenebrio molitor

b. Deskripsi

Ciri-ciri Tenebrio molitor adalah memiliki 1 pasang antenna yang pendek, mata berlekuk, warna hitam mengkilat dan memiliki ukuran panjang tubuh $2 \mathrm{~cm}$ dan lebar tubuh $1 \mathrm{~cm}$, memiliki 3 pasang kaki yang ramping, memiliki rongga-rongga koksa depan tertutup di belakang.

Ciri-ciri lainnya memiliki rongga-rongga koksa depan tertutup dibelakang, mata biasanya berlekuk, sungut hampir selalu 11 ruas baik sebagai bentuk benang atau merjan dan lima sterna abdomen yang kelihatan, kebanyakan berwarna hitam atau coklat gelap dan panjang 1317 mm (Borror, Triplehorn \& Johson 1992)

3. Leptocorisa acuta (Walang sangit)

a. klasfikasi

Kingdom : Animalia

Filum : Athropoda

Kelas : Insekta

Ordo : Hemiptera

Famili : Alydidae

Genus : Leptocorisa

Spesies : Leptocorisa acuta

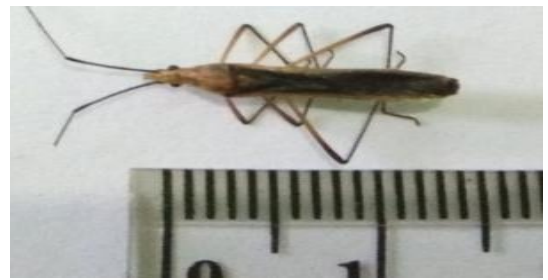

Gambar 3.Leptocorisa acuta 
b. Deskripsi

Ciri-ciri Leptocorisa acuta adalah memiliki 1 pasang antenna, panjang tubuh $1,4 \mathrm{~cm}$ dan lebar $0,3 \mathrm{~cm}$, memiliki warna coklat muda, kepala kecil, mempunyai 3 pasang kaki yang ramping, tubuh panjang dan kurus, mengeluarkan bau busuk, ciri-ciri lainnya memiliki tubuh yang panjang dan sempit, kaki terdiri dari 3 pasang, warna coklat, kekuningkuningan atau hitam, berbau busuk, bertindak sebagai hama atau pemakan tanaman yang dibudidaya (Borror, Triplehorn \& Johson 1992).

4. Tibicen linnei (Tonggeret)

a. klasfikasi

Kingdom : Animalia

Filum : Athropoda

Kelas : Insekta

Ordo : : Homoptera

Famili : Cicadidae

Genus : Tibicen

Spesies : :Tibicen linnei

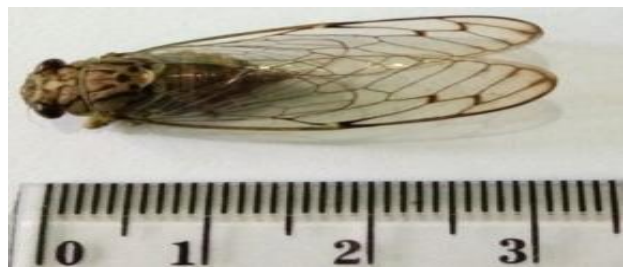

Gambar 4.Tibicen linnei

b. Deskripsi

Ciri-ciri Tibicen linnei mempunyai warna kehitaman dan kehijauan, kepala pendek serta terdapat mata yang besar, sayap lebar dan panjang serta kokoh dan tembus pandang, memiliki ukuran panjang tubuhnya 1.6 $\mathrm{cm}$ dan lebar tubuh $0,8 \mathrm{~cm}$, bentuknya kadang-kadang seperti lalat yang besar, meskipun ada yang berukuran kecil. Ciri-ciri lainnya tonggeret adalah serangga penerbang atau peloncat, memiliki tarsi tiga ruas dan sunggut sangat pendek dan seperti rambut berduri, memiliki ukuran tubuh yang besar dengan sayap-sayap berselaput tipis dan tiga mata tunggal (Borror, Triplehorn \& Johson 1992).

5. Dolichovespula sylvestris (Tawon pohon)

a. klasfikasi

Kingdom : Animalia

Filum : Athropoda

Kelas : Insekta

Ordo : Hymenoptera

Famili : Vespidae

Genus : Dolichovespula 
Spesies: Dolichovespula sylvestris

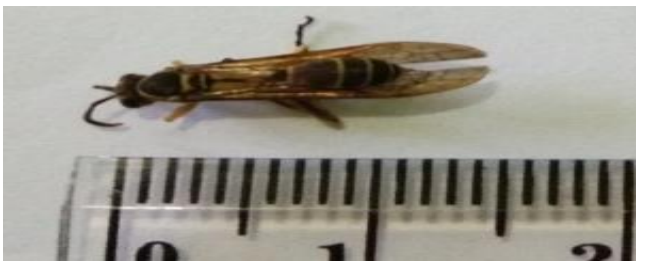

Gambar 5. Dolichovespula sylvestris

b. Deskripsi

Ciri-ciri Dolichovespula sylvestris adalah memiliki 1 pasang antenna, dan ukuran panjang tubuh $1,3 \mathrm{~cm}$, memiliki warna garis-garis kuning dan titik hitam di tengah clypeus-nya, sayapnya berwarna kecoklatan, sarang terbuat dari kertas yang berasal dari kayu.

Ciri-ciri lainnya memiliki abdomen berhubungan dengan thoraks dengan sebuah petioles yang rampin. Sudut belakang pronotum hampir menyentuh tegula.Petiolus tanpa sisik/bonggol/nodus yang tegak. Antenna terdiri atas 13 ruas atau kurang.Sayap melipat longitudinal pada waktu istiraha.Sebagian besar berwarna hitam, beberapa jenis dibagian muka dan abdomen dengan warna kuning (Lilies, 1991).

6. Oecophylla smaragdina (Semut rang-rang)

a. klasfikasi

Kingdom : Animalia

Filum : Athropoda

Kelas : Insekta

Ordo : Hymenoptera

Famili : Formicidae

Genus : : Oecophyla

Spesies : : Oecophyla smaragdina

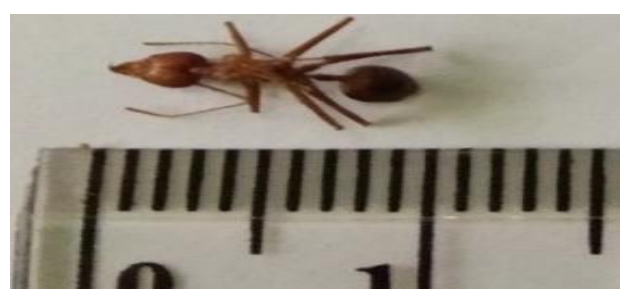

Gambar 6. Oecophyla smaragdina

a. Deskripsi

Ciri-ciri Oecophyla smaragdina memiliki tubuh terbentuk atas kepala, dada dan perut.Panjang tubuhnya $\pm 1 \mathrm{~cm}$, memiliki antena dan kaki yang panjang memiliki abdomen yang berbentuk bongkol dan oval, warna kulit coklat kemerahan, langsing dan aktif bergerak.Semut ini bertindak sebagai predator dan pemakan lainnya. Jika merasa terganggu semut ini akan menggit. 
Ciri-ciri lainnya memiliki beberapa bentuk sayap menyerupai tabuhan-tabuhan.Satu dari sifat-sifat struktural yang jelas dari semut-semut adalah bentuk tangkai (pedicel) metasoma, satu atau dua ruas dan mengandung sebuah gelambir yang mengarah ke atas.Sungut-sungut biasanya menyiku (yang jantan sungut-sungutnya dapat berbentuk seperti rambut), dan ruas pertama seringkali sangat panjang (Borror, Triplehorn \& Johson 1992).

7. Dolichoderus thoracicus (Semut hitam)

a. klasfikasi

Kingdom

: Animalia

Filum : Athropoda

Kelas : Insekta

Ordo : Hymenoptera

Famili : Formicidae

Genus : Dolichoderus

Spesies : : Dolichoderus thoracicus

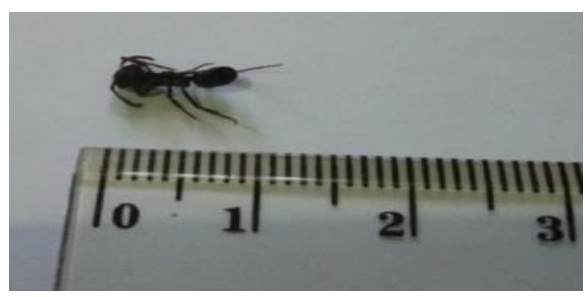

Gambar 7.Dolichoderus thoracicus

b. Deskripsi

Ciri-ciri Dolichoderus thoracicus memiliki tubuh berwarna hitam dengan panjang $0,9 \mathrm{~cm}$, tidak berambut banyak, mempunyai dua antenna yang pendek, tubuh terbagi menjadi tiga bagian yaitu kepala, dada dan perut (abdomen), dan memiliki tonjolan di bagian kepalanya.

Ciri-ciri lainnya memiliki ruas pertama abdomen berbetuk seperti bonggol yang tegak.Antenna 13 ruas atau kurang dan sangat menyiku, ruas pertama panjang.Susunan vena normal atau agak mereduksi.Tidak berambut banyak.Ratu, jantan yang biasanya bersayap, dan pekerja tanpa sayap (Lilies, 1991).

8. Tanaecia iapis (Kupu-kupu hitam biru)

a. klasfikasi

Kingdom : Animalia

Filum : Athropoda

Kelas : Insekta

Ordo : : Lepidoptera

Famili : Nymphalidae

Genus : Tanaecia

Spesies : :Tanaecia iapis 


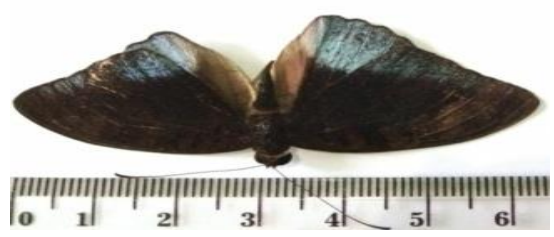

a. Deskripsi

\section{Gambar 8.Tanaecia iapis}

Ciri-ciri Tanaecia iapis adalah memiliki 1 pasang antenna dengan warna dominan hitam dan sedikit warna biru dibagian sayap depan, sedangkan dibagian ujung berwana corak putih, betina jauh lebih pucat dibandingankan dengan yang jantan, panjang sayap $6,4 \mathrm{~cm}$. Ciri-ciri lainnya memiliki ukuran tubuh yang kecil, sayap depan yang berwarna hitam gelap dan memiliki sedikit bagian warna biru di bagian sayap depan, sedangkan pada bagian belakang sayap sama pada bagian depan akan tetapi warna biru lebih banyak dibandingkan warna hitam (Rahman, Dkk, 2018).

9. Idea stolli (Kupu-kupu bintik hitam)

a. klasfikasi

Kingdom : Animalia

Filum : Athropoda

Kelas : Insekta

Ordo : Lepidoptera

Famili : Nymphalidae

Genus : Ide

Spesies $\quad:$ Idea stolli

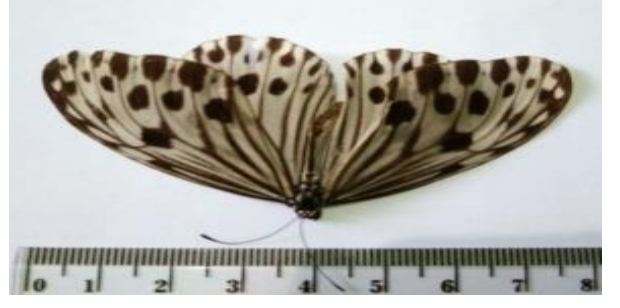

Gambar 9. Idea stolli

b. Deskripsi

Ciri-ciri Idea stolli adalah kupu-kupu yang memiliki warna putih dan bercorak hitam, tidak ada sayap atau vertikal, sayap depan berbentuk segitiga, sayap belakang dengan vena humeral yang memanjang kedepan atau membengkok, panjang sayap $7,7 \mathrm{~cm}$, sel diskal membuka atau menutup dengan vena tipis, kaki depan sangat mengecil, tanpa kuku dan antenna dengan beragam bentuk, tetapi biasanya tidak dengan ujung yang berbentuk bonggol individu ini terkadang terlihat berterbangan di pucuk pohon. 
Ciri-ciri lainnya memiliki banyak warna, coklat oranye, putih dan tanda-tanda hitam, mempunyai sepasang antenna yang pendek, larfa makan berbagai jenis bunga yang lembut dan memiliki 3 pasang kaki (Borror, Triplehorn \& Johson 1992).

10. Valanga nigricornis (Belalang Kayu)

a. klasfikasi

Kingdom : Animalia

Filum : Athropoda

Kelas : Insekta

Ordo : Orthoptera

Famili : Acrididae

Genus : Valanga

Spesies : Valanga nigricornis

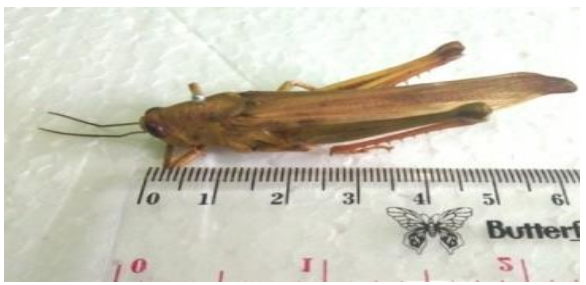

b. Deskripsi

Ciri-ciri Valanga nigricornis adalah memiliki 1 pasang antenna, panjang tubuh 5,3 $\mathrm{cm}$ dan lebar $1,5 \mathrm{~cm}$, mata terlihat jelas, kaki terdiri dari 3 pasang, femur kaki belakang membesar, tubuh berwarna hijau kekuningan dan sayap berwarna kecoklatan, memiliki dua pasang sayap. Ciri-ciri lainnya belalang mempunyai sunggut lebih pendek dari pada tubuh, organ pendengaran (timpana) terletak pada sisi-sisi ruas abdomen pertama. Tarsi 3 ruas dan alat perteluran pendek dan kebanyakan warna kelabu atau kecoklat-coklatan dan beberapa mempunyai warna yang cemerlang pada sayap belakang (Borror, Triplehorn \& Johson 1992).

11. Gryllotalpa orientalis (Orong-orong)

a. klasfikasi

$\begin{array}{ll}\text { Kingdom } & \text { : Animalia } \\ \text { Filum } & \text { : Athropoda } \\ \text { Kelas } & \text { : Insekta } \\ \text { Ordo } & \text { : Orthoptera } \\ \text { Famili } & : \text { Gryllotalpidae } \\ \text { Genus } & \text { : Gryllotalpa } \\ \text { Spesies } & \text { : Gryllotalpa orientalis }\end{array}$




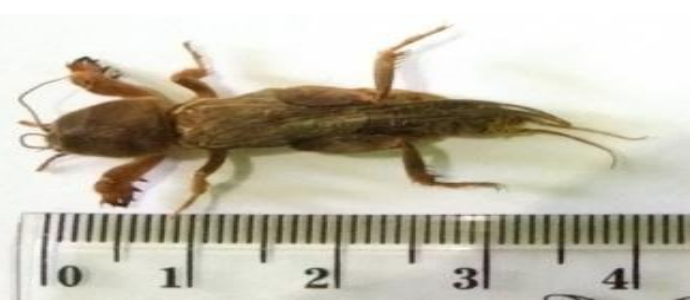

Gambar 11.Gryllotalpa orientalis

a. Deskripsi

Ciri-ciri Gryllotalpa orientalis adalah memiliki 1 pasang antenna berwarna coklat kehitaman, terdiri dari tiga pasang kaki, kaki depan sangat berbeda dengan kaki lainnya karena bentuknya melebar dan berduri, panjang tubuhnya $3,4 \mathrm{~cm}$ dan lebar tubuhnya $0,9 \mathrm{~cm}$, kaki depannya digunakan untuk menggali tanah.

Ciri-ciri lainnya cengkrik penggali tanah ini adalah seranggaserangga yang berbulu kapok (berambut kecil) yang lebat berwarna kecoklat-coklatan dengan sungut yang pendek, dan tungkai-tungkai depannya sangat lebar dan berbentuk sekop. Serangga ini membuat lubang didalam tanh yang lembab seringkali 150-200 mm (Borror, Triplehorn \& Johson 1992).

12. Gryllus bimaculatus (Jangkrik)

a. Klasfikasi

Kingdom : Animalia

Filum : Athropoda

Kelas : Insekta

Ordo : Orthoptera

Famili : Gryllidae

Genus : Gryllus

Spesies : : Gryllus bimaculatus

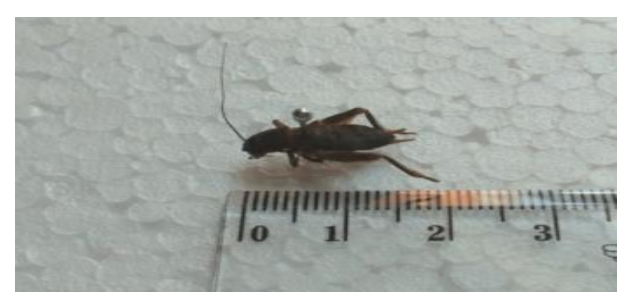

Gambar 12.Gryllus bimaculatus

b. Deskripsi

Ciri-ciri Gryllus bimaculatus adalah memiliki panjang tubuh $1,6 \mathrm{~cm}$ dan lebar $0,5 \mathrm{~cm}$, antenna panjang dan halus seperti rambut, mata terlihat jelas, kaki terdiri dari 3 pasang, kaki belakang lebih lebar dan besar dari pada kaki depan dan tubuh berwarna hitam.

Ciri-ciri lainnya memiliki tubuh berwarna hitam, antenna panjang, memiliki 3 pasang kaki yang digunakan untuk melompat dengan cepat dan 
beberapa jenis pandai menyanyi, sering ditemukan di sawah saat air mongering (Borror, Triplehorn \& Johson 1992).

13. Scambophyllum sanguinolentum (Belalang daun)

a. Klasfikasi

Kingdom : Animalia

Filum : Athropoda

Kelas : Insekta

Ordo : : Orthoptera

Famili : Tettigonidae

Genus : : Scambophyllum

Spesies : :Scambophyllum sanguinolentum

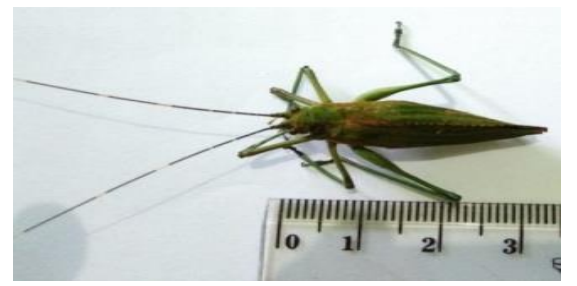

a. Deskripsi

Gambar 13.Scambophyllum sanguinolentum

Ciri-ciri Scambophyllum sanguinolentum adalah memiliki 1 pasang antenna yang panjang dengan ukuran tubuh $3,2 \mathrm{~cm}$, memiliki 3 pasang kaki, tubuh berwarna hijau dan sedikit memiliki warna biru di bagian mata dan kaki. Ciri-ciri lainnya memiliki sungut yang panjang seperti rambut, tarsi yang beruas empat.Hampir semua jenis memiliki organ penghasil suara yang berkembang bagus dan tercatat sebagai individu yang mahir dalam nyanyian (Borror, Triplehorn \& Johson 1992).

14. Acrida conica (Belalang hijau)

a. Klasfikasi

Kingdom : Animalia

Filum : Athropoda

Kelas : Insekta

Ordo : Orthoptera

Famili : Acrididae

Genus : Acrida

Spesies : :Acridaconica conica

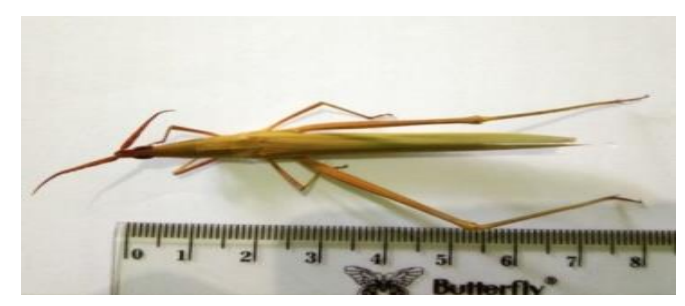

Gambar 14.Acrida conica 
b. Deskripsi

Ciri-ciri Acrida conica adalah memiliki 1 pasang antenna, memiliki panjang tubuh 7,1 cm dan lebar 0,7 cm, warna kecoklat-coklatan, terdiri dari 3 pasang kaki digunakan untuk melompat, kaki belakang lebih panjang dan berisi, Ciri-ciri lainnya memiliki sungut biasanya yang lebih pendek dari pada tubuh, organ pendengaran (timpana) terletak pada sisi-sisi ruas abdomen pertama, tarsi 3 ruas dan alat perteluran pendek.Kebanyakan warnanya kelabu atau kecoklat-coklatan dan beberapa mempunyai warna yang cemerlang pada sayap belakang (Borror, Triplehorn \& Johson 1992).

15. Pantala flavescens (Capung ciwet)

a. Klasfikasi

Kingdom : Animalia

Filum : Athropoda

Kelas : Insekta

Ordo : Odonata

Famili : Libellulidae

Genus : : Pantala

Spesies : Pantala flavescens

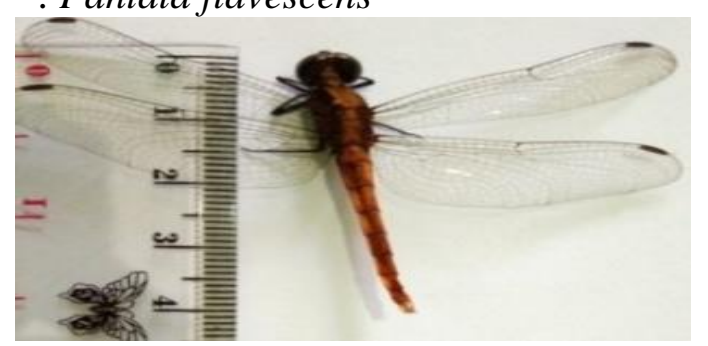

Gambar 15. Pantala flavescens

b. Deskripsi

Ciri-ciri Pantala flavescens adalah memiliki warna sayap bervariasi jenis jantan kebiruan betina hitam kekuningan, memiliki ukuran panjang tubuh $4,1 \mathrm{~cm}$ dan lebar tubuh $0,7 \mathrm{~cm}$, terdiri dari 3 pasang kaki yang ramping. Ciri-ciri lainnya memiliki warna sayap bervariasi dan beberapa jenis mempunyai sayap dengan spot-spot/pita. Sayap jenis jantan kebiruan dan bersih, betina hitam dan kuning, panjang tubuh 4-4,5cm ukuran tubuh sekitar 20-75 mm (Lilies, 1991).

16. Phaenopharos khaoyaiensis (Belalang ranting)

a. Klasfikasi

Kingdom : Animalia

Filum : Athropoda

Kelas : Insekta

Ordo : Phasmida

Famili : Diapheromeridae

Genus : Phaenopharos

Spesies : :Phaenopharoskhaoyaiensis 


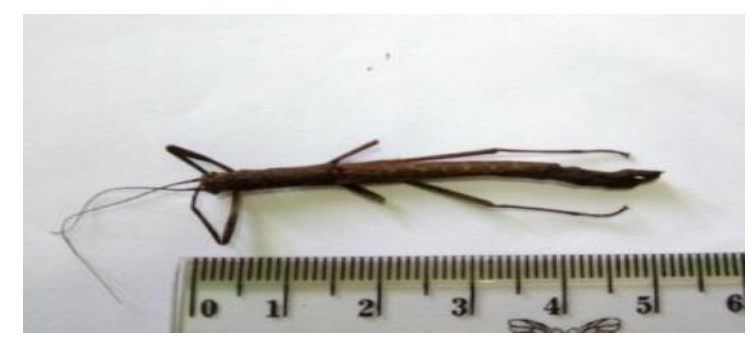

Gambar 16. Phaenopharos khaoyaiensis

b. Deskripsi

Ciri-ciri Phaenopharos khaoyaiensis memiliki 1 pasang antenna panjang dengan ukuran panjang tubuh $\pm 5,3 \mathrm{~cm}$ dan berwarna kecoklatan dapat ditemukan di pepohonan atau semak-semak belukar dengan menyerupai ranting tanaman.

Ciri-ciri lainnya memiliki femur belakang yang membesar (dan mereka tidak meloncat) dan tarsi biasanya lima ruas, jenis ini memiliki tubuh yang memanjang dan seperti tongkat dan sayap-sayap sangat menyusut atau sama sekali tidak ada, serangga ini tidak mempunyai timpana dan organ penghasil bunyi, sersinya pendek dan satu ruas, ovipositor pendek dan tersembunyi, mereka sangat menyerupai ranting dengan memiliki nilai perlindungan (Borror, Triplehorn \& Johson 1992) .

\section{PEMBAHASAN}

Berdasarkan hasil penelitian yang telah dilakukan, jenis-jenis Insekta yang ditemukan di Hutan Pendidikan dan Pelatihan Universitas Muhammadiyah Bengkulu Kabupaten Bengkulu Tengah, ditemukan Insekta yang terdiri dari 8 Ordo, 13 Famili dan 16 Spesies debagai berikut : Ordo Coleoptera yaitu dari famili Carabidae terdiri dari 1 spesies Pheropsophus verticalis (Kumbang macan), famili Tenebrionidae terdiri dari 1 spesies Tenebrio molitor (Kumbang ulat), Ordo Hemiptera yaitu dari famili Alydidae terdiri dari 1 spesies Leptocorisa acuta (Walang sangit), Ordo Homoptera yaitu dari famili Cicadidae terdiri dari 1 spesies Tibicen linnei (Tonggeret), Ordo Hymenoptera yaitu dari famili Vespidae terdiri dari 1 spesies Dolichovespula sylvestris (Tawon pohon), famili Formicidae terdiri dari 2 spesies yaitu Oecophylla smaragdina (Semut rang-rang), Dolichoderus thoracicus (Semut hitam), Ordo Lepidoptera yaitu dari famili Nymphalidae terdiri dari 2 spesies yaitu Tanaecia iapis (Kupu-kupu hitam biru), Idea stoli (Kupu-kupu bintik hitam), Ordo Orthoptera yaitu dari famili Acrididae terdiri dari 2 spesies yaitu Valanga nigricornis (Belalang kayu), Acrida conica (Belalang hijau), famili Gryllidae terdiri dari 1 spesies Gryllus bimaculatus (Jangkrik), famili Tettigonidae terdiri dari 1 spesies Scambophyllumson guinolentum (Belalang katydid), famili Gryllotalpidae terdiri dari 1 spesies Gryllotapa orientalis (Anjing tanah), Ordo Odonata yaitu dari famili Libellulidae terdiri dari 1 spesies Pantala flavescens (Capung ciwet), Ordo Phasmida yaitu dari 
famili Diapheromeridae terdiri dari 1 spesies Phaenopharos khaoyaiensis (Belalang ranting).

Tabel 1. Ordo yang paling banyak ditemukan familinya yaitu Orthoptera dengan 4 famili yaitu : Acricidae, Gryllidae, Tettigoniidae, Gryllotalpidae. Paling banyaknya famili dari Ordo Orthoptera pada lokasi penelitian ditemukan disebabkan area hutan cocok untuk jenis Ordo Orthoptera mendapatkan sumber makanan mulai dari dedaunan hingga bunga pada tanaman, dan juga ditemukan oleh faktor lingkungan. Dari data hasil penelitian di dapat suhu berkisar $26^{\circ} \mathrm{C}$ $31^{\circ} \mathrm{C}$ dengan rata-rata sebesar $28^{\circ} \mathrm{C}$ yang cocok untuk kehidupan ordo Orthoptera ini.Hal ini sesuai pendapat (Prakoso, 2017) keanekaragaman belalang (Ordo orthoptera) secara umum juga ditentukan oleh faktor lingkungan, bahwa suhu pada hutan berkisar antara $21-39^{\circ} \mathrm{C}$ dengan rata-rata sebesar $30^{\circ} \mathrm{C}$ cocok untuk serangga (Ordo orthoptera).Selain itu, berbagai jenis tumbuh-tumbuhan yang ada di area juga menjadi penentu keanekaragaman serangga. Menurut Borror, dkk (1992), menyatakan bahwa kebanyakan spesies dari Ordo Orthoptera merupakan pemakan tumbuh-tumbuhan, dan beberapa dari serangga ini adalah hama-hama yang penting bagi tanaman budidaya dan beberapa lagi sebagai predator.

Ordo yang relatif banyak ditemukan yaitu Ordo Coleoptera dengan 2 famili yaitu Carabidae dan Tenebrionidae dan Ordo Hymenoptera dengan 2 famili yaitu Vespidae dan Formicidae. Banyaknya famili dari Ordo Coleoptera yang ditemukan dilokasi penelitian disebabkan terdapat banyak ketersediaan makanan seperti dedaunan hingga bunga pada tanaman dan memangsa berbagai serangga yang ditemukan di permukaan tanah.Hal ini sesuai pendapat (Borror, Triplehorn \& Johson 1992) menyatakan bahwa Ordo Coleoptera dapat ditemukan pada hampir setiap tipe habitat dan mereka makan segala macam bahan tumbuhtumbuhan dan hewan. Banyaknya famili dari Ordo Hymenoptera yang ditemukan dilokasi penelitian disebabkan oleh sumber makanan yang cocok karena banyak sisa-sisa daun yang gugur di atas permukaan tanah yang banyak mengandung unsur hara. Hal ini sesuai pendapat (Rahmawaty, 2004) menyatakan bahwa keberadaan Ordo Hymenoptera sangat tergantung pada ketersediaan energi dan sumber makanan untuk kelangsungan hidupnya, dengan adanya ketersediaan energi dan hara, maka perkembangan dan aktivitas akan berlangsung baik dan timbal baliknya memberikan dampak positif bagi kesuburan tanah.

Ordo yang paling sedikit ditemukan yaitu Ordo Hemiptera dengan 1 famili yaitu Alydidae, Ordo Homoptera dengan 1 famili yaitu Cicadidae, Ordo Lepidoptera dengan 1 famili yaitu Nymphalidae, Ordo Odonata dengan 1 famili yaitu Libellulidae dan Ordo Phasmida dengan 1 famili yaitu Diapheromeridae. Walaupun faktor makanan tersedia banyak yaitu berupa dedaunan hingga bunga pada tanaman di lokasi, tapi ada faktor ekologi yang kurang cocok untuk kehidupan ordo-ordo tersebut. Karena pada lokasi penelitian terjadinya musim hujan yang berdampak pada keberadaan ordo-ordo ini. Menurut Hasyimuddin, et al, (2017) menyatakan bahwa secara teroritis hewan secara aktif akan berpindah 
dari satu lingkungan ke lingkungan yang lain, apabila terjadi perubahan lingkungan sementara misalnya hujan. Dengan berpindah dari lingkungan yang berubah, hewan akan dapat tinggal pada rentangan kondisi lingkungan yang optimum bagi mereka.

Pada tabel 2. juga dapat dilihat Jumlah Insekta yang ditemukan sebanyak 326 individu. Insekta yang paling banyak ditemukan di Hutan Universitas Muhammadiyah Bengkulu Kabupaten Bengkulu Tengah yaitu famili Formicidae spesies Oecophylla smaragdina (Semut rang-rang) dengan jumlah 63 individu, Dolichovespula sylvestris (Semut hitam) dengan jumlah 60 individu dari famili Formicidae, jenis Insekta ini banyak ditemukan karena semut memiliki keanekaragaman yang tinggi dan memiliki kemampuan adaptasi sehingga keberadaanya dapat ditemukan. Hal ini famili Formicidae cocok hidup diwilayah penelitian dengan suhu berkisar antara $26^{\circ} \mathrm{C}-31^{\circ} \mathrm{C}$ dengan rata-rata sebesar $28^{\circ} \mathrm{C}$. Hal ini sesuai pendapat (Riyanto, 2007), menyatakan bahwa Kisaran suhu udara antara $25^{\circ} \mathrm{C}-32^{\circ} \mathrm{C}$ merupakan suhu optimal dan toleran bagi aktivitas semut di daerah tropis. Sedangkan menurut Rahmawati (2004) menyatakan kisaran suhu udara pada mesofauna tanah termasuk insekta, yaitu antara $29,6{ }^{\circ} \mathrm{C}$ sampai $32,1^{\circ} \mathrm{C}$.

Insekta yang paling sedikit ditemukan di lokasi penelitian adalah pada famili Gryllotalpidae dengan spesies Gryllotapa orientalis, Spesies ini ditemukan 3 individu .Jenis Insekta ini ditemukan paling sedikit karena dari data hasil penelitian di dapat suhu berkisar antara $26^{\circ} \mathrm{C}-31^{\circ} \mathrm{C}$ dengan rata-rata sebesar $28^{\circ} \mathrm{C}$ yang tidak sesuai dengan spesies anjing tanah ini.hewan yang agak jarang terlihat dan lebih suka bersembunyi dalam lubang dan aktif pada malam hari untuk mencari makanan. Habitat yang disukai seperti tanah yang kering, lapangan rumput dan ditemukan disemua tempat kecuali daerah kutub bumi. Menurut Prakoso (2017) keragaman hewan ini dipengaruhi oleh faktor-faktor ekologis diantarnya adalah pola curah hujan,suhu atmosfer.

Pada tabel 3. indeks kekaragaman jenis di peroleh dengan menghitung indeks keanekaragaman jenis Shannon-Wienner (H'). Dari hasil perhitungan indeks keanekaragaman jenis dalam penelitian ini diperoleh yaitu $\mathrm{H}^{\prime}=1,031 \mathrm{di}$ kategorikan indeks keanekaragaman sedang. Hal ini sesuai pendapat (Andrian, 2017) keanekaragaman serangga memiliki 3 kriteria yaitu, bila $H^{\prime}<1$ berarti keanekaragaman serangga tergolong rendah, bila $H^{\prime}=1-3$ berarti keanekaragaman serangga tergolong sedang, bila $\mathrm{H}^{\prime}>3$ berarti keanekaragaman serangga tergolong tinggi. Nilai tersebut menunjukkan bahwa nilai keanekaragaman jenis serangga berada pada kategori sedang dan menunjukkan bahwa kondisi lingkungan tersebut masih cukup seimbang karena suhu dapat mempengaruhi pertumbuhan dan perkembangan serangga.Suhu tinggi mempercepat pertumbuhan dan perkembangan dan juga mempercepat kematian sedangkan suhu rendah membuat metabolisme serangga rendah sehingga mampu bertahan hidup dengan jumlah persediaan makanan yang sedikit. Hal ini sesuai pendapat (Haneda, dkk, 2013) 
tingginya indeks keanekaragaman dan kemerataan serangga menunjukkan habitat lebih stabil dibandingkan habitat lainnya dan ketersediaan sumber daya yang mendukung kehidupan serangga. Sehingga heterogen suatu lingkungan fisik semakin kompleks komunitas flora dan fauna disuatu tempat tersebut dan semakin tinggi keragaman jenisnya.

Pada tabel 4. Data ekologi yang diukur dan diperoleh pada pagi hari jam 08.00-10.00 WIB, siang jam 12.00-14.00 WIB dan sore jam 15.00-17.00 WIB, Suhu berkisaran antara $26^{\circ} \mathrm{C}-31^{\circ} \mathrm{C}$ dengan rata-rata $28^{\circ} \mathrm{C}$ cocok untuk kehidupan Insekta sehingga mempengaruhi keanekaragaman Insekta di lokasi penelitian. Hal ini sesuai pendapat (Jumar, 2000) menyatakan bahwa kisaran suhu yang efektif untuk serangga adalah suhu minimum $15^{\circ} \mathrm{C}$, suhu optimum $25^{\circ} \mathrm{C}$, dan suhu maksimum $45^{\circ} \mathrm{C}$. Sedangkan kelembaban berkisar antara $87 \%-90 \%$ cocok untuk kehidupan Insekta, karena kelembaban udara mempengaruhi pembiakan, pertumbuhan, perkembangan dan keaktifan Insekta. Hal ini sesuai pendapat (Pariyanto, dkk, 2017). Pada kelembaban $70 \%$ dengan suhu $18^{\circ} \mathrm{C}$, maka masa jadi telur sampai dewasa lamanya 110 hari, sedangkan bila kelembaban $89 \%$ dengan suhu yang sama lamanya 90 hari. Hal ini menunjukan bahwa kelembaban yang tinggi akan memperpendek siklus hidup serangga.

\section{SIMPULAN}

Hasil penelitian, insekta yang ditemukan, diperoleh 326 individu yang terdiri dari 13 famili dengan 16. Dari seluruh famili Insekta yang ditemukan diperoleh Indeks Keanekaragaman sebesar 1,031 yang menunjukan bahwa keanekaragaman tergolong sedang. Hasil pengukuran faktor ekologi di hutan yaitu suhu berkisar antara $26^{\circ} \mathrm{C}-31^{\circ} \mathrm{C}$ dan kelembaban $87 \%-90 \%$.

\section{DAFTAR PUSTAKA}

Arief, A. (2001). Hutan \& Kehutanan. Yogyakarta: Penerbit Kanisus.

Andrian , R., F \& Maretta, G. (2017). Keanekaragaman Serangga Pollinator pada Bunga Tanaman tomat (Soalnum Lycopersicum) di Kecamatan Gisting Kabupaten Tanggamus. Jurnal Tadris Pendidikan Biologi 8(1);105- 113.

Borror, D. J., Triplehorn. C., A. \& Johson, N., F. (1992). Pengenalan Pelajaran Serangga Edisi Ke-enam. Gajah Mada Univesity Press. Yogyakarta.

Fakhrah. (2016). Inventarisasi Insekta Permukaan Tanah Di Gampong Krueng Simpo Kecamatan Juli Kabupaten Bireuen. Jurnal Pendidikan Almuslim, $4(1)$

Hadi, M. H., Udi, T \& Rully, R. (2009). Biologi Insekta Entomologi. Graha Ilmu. Yogyakarta.

Hamama, S., F \& Sasmita, I. (2017). Keanekaragaman Serangga Permukaan Tanah Di Sekitar Perkebunan Desa Cot Kareung Kecamatan Indrapuri Kabupaten Aceh Besar. JESBIO 6(1).

Hasyimuddin, S \& Usaman, A., A. (2017). Peran Ekologis Serangga Tanah di Perkebunan Patallassang Kecamatan Patallassang Kabupaten Gowa 
Sulawesi Selatan. Prosiding Seminar Nasional Biology for Life. 10 November 2017. ISBN: 978-602-72245-2-0.

Hasan,R., Yuniarti, A \& Kasmiruddin. (2018). Keanekaragaman Liana Di Hutan Pendidikan Universitas Muhammadiyah Bengkulu, Kabupaten Bengkulu Tengah. Jurnal Sains Teknologi \& LingkungaN 4(1); 1-11.

Haneda, N.F., Kusuma, C \& Kusuma, F.D. (2013). Keanekaragaman serangga di ekosistem Mangrove. Jurnal Silvikultur Tropika 4(1), 105-113

Kemeterian Perencanaan Pembangunan Nasional/BAPPENAS, (2016). Indonesian Biodiversity Strategy and Action Plan (IBSAP) 2015-2020.

Irianto, K. (2009). Memahami Dunia Serangga. Sarana Ilmu Pustaka. Bandung Indriyanto. (2008). Ekologi Hutan. Penerbit Bumi Aksara. Jakarta Indrawan. (2012). Biologi Konservasi. Jakarta: Yayasan Pustaka Obor Indonesia. Jumar. (2000). Entomologi Pertanian. Rineke Cipta, Jakarta Keputusan Menteri Lingkungan Hidup dan Kehutan Republik Indonesia No.SK. 425/Menlhk/Setjen/PLA.0/6/2016 tentang Penetapan Kawasan Hutan Dengan Tujuan Khusus Pada Kawasan Hutan Lindung Yang Terletak Di Kabupaten Bengkulu Tengah, Provinsi Bengkulu Seluas \pm 2000 (Dua Ribu) Ha Sebagai Hutan Pendidikan Dan Pelatihan. Jakarta.

Lilies. C. S. (1991). Kunci Determinasi Serangga. Kansius.Yogyakarta.

Mantu, D. (2016). Keanekaragaman Dan Peran Ekologi Serangga Nokturnal Pada Kebun Nilam (Pogostemon Cablin) Kecamatan Tinondo Kabupaten Kolaka Timur Sulawesi Tenggara. Skripsi Jurusan Biologi FMIPA Universitas Halu Oleo Kendari

Murniningtyas. (2016). Indonesia biodiversity Strategy and Action Plan. Bappenas: Jakarta.

Pemerintah Kabupaten Bengkulu Tengah. 2016. Laporan Kinerja Instansi Pemerintah Kabupaten Bengkulu tengah 2017. Bengkulu Tengah.

Prakoso, B. (2017). Biodiversitas Belalang (Acrididae: ordo Orthoptera) pada Agroekosistem (zea mays 1.) dan Ekosistem Hutan Tanaman di Kebun Raya Baturaden, Banyumas. Biosfer 34 (2), 80-88.

Pariyanto, S \& Suherman. (2017). Jenis-jenis Serangga Yang Terdapat Di Persawahan Desa Marga Mulya Kecamatan Kikim Timur Kabupaten Lahat. Biodiversitas 30(2).

Rahmawaty. (2004). Studi Keanekaragaman Mesofauna Tanah Di Kawasan Hutan Wisata Alam Sibolangit. Universitas Sumatera Utara

Rachmasari, D.O. Prihanta, W \& Susetyarini, E.R. (2016). Keanekaragaman Serangga Permukaan Tanah Di Arboretum Sumber Brantas Batu-Malang Sebagai Dasar Pembuatan Sumber Belajar Flipchart. Jurnal Pendidikan Biologi Indonesia. 2(2).

Ridhwan. (2012). Tingkat Keanekaragaman Hayati Dan Pemanfaatannya Di Indonesia . Banda Ache. Jurnal Biology Education 1(1)

Rahman, A. Kartikawati, S.M. \& Rifanjani, S. (2018). Jenis Kupu-kupu, Di Berbagai Tipe Habitat Pada Kawasan Hutan Lindung Ambawang Desa Sungai Deras Kecamatan Teluk Pakedai Kabupaten Kubu Raya. Jurnal Hutan LestarI 5(1); 98-106.

Riyanto. (2007). Kepadatan, Pola distribusi dan Peranan Semut Pada Tanaman Di Sekitar Lingkungan Tempat Tinggal. Jurnal Penelitian Sains 10(2); 241 253. 
Sulistyani, H., T. Rahayuningsih, \& M. Partaya. (2014). Keanekaragaman Serangga Di Cagar Alam Ulolanang Kecubung Kabupaten Batang. Universitas Negeri Semarang

Sembel, D. T. (2010). Pengendalian Hayati Hama-Hama Serangga Tropis dan Gulma. Graha Ilmu. Andy. Yogyakarta

Sari, L., S. Putri, R., R \& Sumiati. (2016). Keanekaragaman Serangga Pada Perdu Di Kawasan Pesisir Desa Rinon Pulo Breuh Kabupaten Aceh Besar. Prosiding Seminar Nasional Biotik. ISBN: 978-602-18962-9-7.

Soegianto.(1994). Ekologi kualitatif. Surabaya: Usaha Nasional. 